\title{
Role of the Hippocampus, the Bed Nucleus of the Stria Terminalis, and the Amygdala in the Excitatory Effect of Corticotropin- Releasing Hormone on the Acoustic Startle Reflex
}

\author{
Younglim Lee and Michael Davis \\ Department of Psychiatry, Yale University, New Haven, Connecticut 06508
}

Previously, we demonstrated that transection of the fimbria/ fornix blocked the excitatory effect of corticotropin-releasing hormone $(\mathrm{CRH})$ on startle $(\mathrm{CRH}$-enhanced startle), suggesting that the hippocampus and its efferent target areas that communicate via the fimbria may be critically involved in $\mathrm{CRH}$ enhanced startle. The bed nucleus of the stria terminalis (BNST) receives direct projections from the ventral hippocampus via the fimbria/fornix. Therefore, the role of the ventral hippocampus, the BNST, and the amygdala in $\mathrm{CRH}$-enhanced startle was investigated. NMDA lesions of the BNST completely blocked $\mathrm{CRH}$-enhanced startle, whereas chemical lesions of the ventral hippocampus and the amygdala failed to block $\mathrm{CRH}$-enhanced startle. However, the same amygdala-lesioned animals showed a complete blockade of fear-potentiated startle, a conditioned fear response sensitive to manipulations of the amygdala. In contrast, BNST-lesioned rats had normal fear-potentiated star- tle. This indicates a double dissociation between the BNST and the amygdala in two different paradigms that enhance startle amplitude. Microinfusions of $\mathrm{CRH}$ into the BNST, but not into the ventral hippocampus, mimicked intracerebroventricular $\mathrm{CRH}$ effects. Furthermore, infusion of a $\mathrm{CRH}$ antagonist into the BNST blocked $\mathrm{CRH}$-enhanced startle in a dose-dependent manner. Control studies showed that this blockade did not result from either leakage of the antagonist into the ventricular system or a local anesthetic effect caused by infusion of the antagonist into the BNST. The present studies strongly suggest that $\mathrm{CRH}$ in the CSF can activate the BNST, which could lead to activation of brainstem and hypothalamic BNST target areas involved in anxiety and stress responses.

Key words: bed nucleus of the stria terminalis (BNST); amygdala; hippocampus; corticotropin-releasing hormone (CRH); startle; anxiety; fear
Intracerebroventricular infusion of corticotropin-releasing hormone (CRH) elicits a constellation of behavioral, physiological, and endocrinological changes similar to those produced by natural stressors (cf. Dunn and Berridge, 1990). Thus far, however, the exact anatomical sites responsible for these behavioral and physiological actions of CRH after intracerebroventricular administration have not been identified. As part of an effort to delineate the neural circuitry underlying intracerebroventricular $\mathrm{CRH}$ effects, recently we investigated a possible involvement of the septum, using increased acoustic startle amplitude after $\mathrm{CRH}$ (CRH-enhanced startle) as a behavioral measure (Lee and Davis, 1997). Electrolytic lesions of the whole septum and the medial septum, but not the lateral septum, blocked CRH-enhanced startle. However, fiber-sparing chemical lesions of the medial septum failed to block CRH-enhanced startle, suggesting that the blockade seen with electrolytic lesions was probably caused by damage to fibers of passage, presumably the fornix. Supporting this conclusion, functional lesions of the fornix induced by knife cuts of the fimbria/fornix completely blocked CRH-enhanced startle.

The fimbria/fornix is the main output pathway for the hippocampus (cf. Amaral and Witter, 1995). Therefore, the blockade of $\mathrm{CRH}$-enhanced startle by transection of the fimbria/fornix

Received Jan. 13, 1997; revised May 21, 1997; accepted May 29, 1997.

This research was supported by National Institute of Mental Health Grant MH-47840, Research Scientist Development Award MH-00004 to M.D., a Grant from the Air Force Office of Scientific Research, and the state of Connecticut.

Correspondence should be addressed to Dr. Michael Davis, Yale University, Department of Psychiatry, Connecticut Mental Health Center, 34 Park Street, New Haven, CT 06508.

Copyright (C) 1997 Society for Neuroscience $\quad 0270-6474 / 97 / 176434-13 \$ 05.00 / 0$ suggests that the hippocampus might be critically involved in CRH-enhanced startle. Among its subdivisions, however, the dorsal hippocampus seems not to be involved, because electrolytic lesions of this area did not block CRH-enhanced startle (Lee and Davis, 1997). A possible involvement of the ventral hippocampus in CRH-enhanced startle has not been investigated. Interestingly, the ventral hippocampus projects to the bed nucleus of the stria terminalis (BNST) via the fimbria/fornix (cf. Canteras and Swanson, 1992; Cullinan et al., 1993; Amaral and Witter, 1995). Furthermore, both the ventral hippocampus and the BNST contain a moderate amount of CRH receptors (De Souza et al., 1984; Chalmers et al., 1995; Sawchenko and Swanson, 1985). Therefore, it is conceivable that $\mathrm{CRH}$ given intracerebroventricularly primarily binds to the ventral hippocampus and modulates startle amplitude via hippocampal-BNST connections. Alternatively, both the ventral hippocampus and the BNST may be the primary receptor sites for $\mathrm{CRH}$ given intracerebroventricularly.

The amygdala complex also has been implicated in $\mathrm{CRH}$ enhanced startle. Liang and colleagues (1992) reported that electrolytic lesions of the amygdala blocked CRH-enhanced startle, whereas $\mathrm{CRH}$ infused into the amygdala failed to mimic intracerebroventricular $\mathrm{CRH}$ effects on startle. Because the amygdala has direct projections to the nucleus reticularis pontis caudalis (Hitchcock and Davis, 1991), a part of the primary acoustic startle circuit (Davis et al., 1982; Lee et al., 1996), these data suggest that the amygdala may play an obligatory role in CRH-enhanced startle, even though it is not the primary receptor site for $\mathrm{CRH}$ given intracerebroventricularly. In other words, $\mathrm{CRH}$ given intracerebroventricularly may bind to receptors in structures afferent to the amygdala, such as the BNST or hippocampus, thereby 
exciting the amygdala indirectly. In turn this would lead to an increase in startle amplitude via the direct connections between the amygdala and the nucleus reticularis pontis caudalis.

In the present series of studies we attempted to determine the location of the primary receptor site(s) for intracerebroventricular $\mathrm{CRH}$ using the $\mathrm{CRH}$-enhanced startle paradigm. Three criteria were considered to be necessary for a given structure $x$ to be identified as a primary receptor site for $\mathrm{CRH}$ given intracerebroventricularly. First, chemical lesions of structure $x$ should block intracerebroventricular CRH effects. Second, CRH inf used directly into structure $x$ should mimic intracerebroventricular $\mathrm{CRH}$ effects. Third, a CRH antagonist infused directly into structure $x$ should antagonize effects of $\mathrm{CRH}$ given intracerebroventricularly. Based on these three criteria, the present studies examined the role of the BNST, ventral hippocampus, and amygdala complex in CRH-enhanced startle.

\section{MATERIALS AND METHODS}

\section{Animals}

Male Sprague Dawley rats (Charles River, Kingston, NY) weighing $350-450 \mathrm{gm}$ were used. The animals were housed in groups of three before surgery in $20 \times 24 \times 36 \mathrm{~cm}$ hanging wire cages and were housed singly in $19 \times 20 \times 25 \mathrm{~cm}$ wire cages after surgery. The animal colony was on a $12 \mathrm{hr}$ light/dark schedule (lights on at 7 A.M.) with food and water continuously available.

\section{Startle apparatus}

The startle apparatus is been described in detail in the accompanying article (Lee and Davis, 1997). Briefly, five separate stabilimeters consisting of an $8 \times 15 \times 15 \mathrm{~cm}$ Plexiglas and wire mesh cage suspended between compression springs within a steel frame were used. Cage movement resulted in displacement of an accelerometer where the resultant voltage was proportional to the velocity of cage displacement. Startle amplitude was defined as the peak accelerometer voltage that occurred during the first $200 \mathrm{msec}$ after onset of the startle stimulus.

The startle stimuli were delivered by high-frequency Radio Shack super tweeters located $10 \mathrm{~cm}$ behind each stabilimeter. Startle stimuli were $50 \mathrm{msec}$ bursts of white noise at various intensities. Throughout all experiments, background white noise was $55 \mathrm{~dB}$.

Presurgery matching. Three to 4 weeks after delivery, the animals were placed in the startle test cages and given a presurgery matching test consisting of a 5 min acclimation period followed by 60 startle eliciting noise bursts at $105 \mathrm{~dB}$, at a $30 \mathrm{sec}$ intertrial interval (ITI). The animals were subsequently divided into sham or lesion groups, having similar mean startle amplitudes across the last 10 startle stimuli.

\section{Surgery}

NMDA lesions of the BNST, ventral hippocampus, and basolateral nucleus of the amygdala and ibotenic acid lesions of the central nucleus of the amygdala. The lesions were made by infusing $200 \mathrm{nl}$ of NMDA (20 $\mathrm{mg} / \mathrm{ml}$ ) into the BNST or the ventral hippocampus over $4 \mathrm{~min}$. The coordinates relative to bregma were $-0.2 \mathrm{~mm}$ anteroposterior (AP), $\pm 1.7 \mathrm{~mm}$ mediolateral (ML) and $-6.8 \mathrm{~mm}$ dorsoventral (DV) for the BNST $(n=20)$, and $-4.8 \mathrm{~mm} \mathrm{AP,} \pm 5.0 \mathrm{~mm} \mathrm{ML}$, and $-8.0 \mathrm{~mm} \mathrm{DV}$ for the ventral hippocampus $(n=40)$. For lesions of the basolateral nucleus of the amygdala (BLA; $n=15$ ), NMDA was infused in two different locations, using the following coordinates relative to bregma: $-2.7 \mathrm{~mm}$ $\mathrm{AP}, \pm 5.2 \mathrm{~mm} \mathrm{ML}$, and $-8.6 \mathrm{~mm} \mathrm{DV}(200 \mathrm{nl} / 4 \mathrm{~min})$ and $-2.7 \mathrm{~mm} \mathrm{AP}$ $\pm 5.2 \mathrm{~mm} \mathrm{ML}$, and $-8.3 \mathrm{~mm} \mathrm{DV}(100 \mathrm{nl} / 2 \mathrm{~min})$. Lesions of the central nucleus of the amygdala $(\mathrm{CeA})$ were made using ibotenic acid (Research Biochemicals, Natick, MA), because a pilot study showed that ibotenic acid was more effective than NMDA in lesioning the CeA without much damage to the BLA. One hundred fifty nanoliters of the ibotenic acid solution $(15 \mathrm{mg} / \mathrm{ml}$ in $0.1 \mathrm{M}$ PBS, $\mathrm{pH} 7.4)$ was infused over $3 \mathrm{~min}$ at the following coordinates relative to bregma: $-2.2 \mathrm{~mm} \mathrm{AP,} \pm 4.3 \mathrm{~mm} \mathrm{ML}$, and $-8.6 \mathrm{~mm} \mathrm{DV}(n=15)$. For the control animals $(n=15)$, an equivalent amount of phosphate buffer was infused into the ventral hippocampus, amygdala, or BNST ( $n=5$ in each case), using the procedures described above.

Intra-BNST and intraventral hippocampus cannula implantation. The BNST was cannulated bilaterally using the following coordinates with respect to bregma: $-0.5 \mathrm{~mm} \mathrm{AP,} \pm 1.5 \mathrm{~mm} \mathrm{ML}$, and $-7.8 \mathrm{~mm} \mathrm{DV}(n=$ 10). Cannulation of the ventral hippocampus was also bilateral, and the coordinates with respect to bregma were $-4.8 \mathrm{~mm} \mathrm{AP,} \pm 5.0 \mathrm{~mm} \mathrm{ML}$, and $-8.0 \mathrm{~mm} \mathrm{DV}(n=15)$.

Intra-BNST, lateral ventricle, or intra-CeA cannulation combined with intracisternal cannulation. In different animals, the BNST, lateral ventricles, or CeA were cannulated bilaterally with concomitant intracisternal cannulation. The coordinates with respect to bregma were $-2.3 \mathrm{~mm} \mathrm{AP}$, $\pm 4.0 \mathrm{~mm} \mathrm{ML}$, and $-9.0 \mathrm{~mm} \mathrm{DV}(\mathrm{CeA} ; n=10) ;-0.5 \mathrm{~mm} \mathrm{AP}, \pm 1.5 \mathrm{~mm}$ $\mathrm{ML}$, and $-5.0 \mathrm{~mm} \mathrm{DV}$ (lateral ventricles; $n=7$ ); and $-0.5 \mathrm{~mm} \mathrm{AP,} \pm 1.5$ $\mathrm{mm} \mathrm{ML}$, and $-7.8 \mathrm{~mm} \mathrm{DV} \mathrm{(BNST;} n=10)$. The coordinates for intracisternal cannulation were $-11.6 \mathrm{~mm} \mathrm{AP}, \pm 0.0 \mathrm{~mm} \mathrm{ML}$, and -7.8 $\mathrm{mm}$ DV.

\section{Test procedure and drug administration}

Postsurgery matching. One week after surgery, the animals were tested with an identical matching procedure used for presurgery matching. The decision regarding which animals would be infused with $\mathrm{CRH}$ on test 1 and which would be inf used with artificial CSF (ACSF) was made so that the mean startle amplitudes across the last 10 trials in the postmatching test were equivalent in the $\mathrm{CRH}$ and vehicle groups in a given test day.

Intracerebroventricular CRH test. The effect of intracerebroventricular $\mathrm{CRH}$ on startle was tested $1 \mathrm{~d}$ after postsurgery matching. The animals were given a predrug baseline test, which was identical to the matching test. Immediately after the test, the animals were removed from the cage, and half were infused with CRH $(1 \mu \mathrm{g} / 5 \mu \mathrm{l}$ over $2 \mathrm{~min}$; human/rat CRH, Peninsula Laboratory), whereas the other half were infused with the vehicle ACSF (5 $\mu \mathrm{l} / 2 \mathrm{~min})$. After intracerebroventricular infusion, the animals were placed back in the startle chambers and presented with 240 startle-eliciting noise bursts at a $30 \mathrm{sec}$ ITI (post-drug test). Forty-eight hours later, the animals were tested again using a crossover design in which the animals infused with CRH on test 1 were infused with ACSF on test 2 and vice versa.

Intra-BNST and intraventral hippocampus infusion of $C R H$. The general protocol for testing the effects of CRH directly infused into the BNST and the ventral hippocampus on startle was similar to that used in testing the effects of intracerebroventricular CRH on startle. Immediately after the predrug baseline test, the animals were removed from the cage and infused bilaterally with one of four doses of CRH into the BNST [0 (ACSF), 40, 80, or $160 \mathrm{ng} / 0.6 \mu \mathrm{l}$ total] over $3 \mathrm{~min}$. Subsequently, the animals were placed back into the startle chambers and given a postdrug test as described above. The test was $2 \mathrm{hr}$ long, consisting of 240 startle trials. This rather long test session was chosen, because a pilot study showed that the excitatory effect of CRH on startle after intra-BNST infusion lasted as long as the intracerebroventricular $\mathrm{CRH}$ effect on startle. All animals were tested four times with each of the CRH doses. Each test was $48 \mathrm{hr}$ apart, and the injection order was based on a Latin square design. For intraventral hippocampus inf usions of $\mathrm{CRH}$, inf usion and testing procedures were identical to those of the intra-BNST study, except three rather than four doses of CRH $(0,40$, and $80 \mathrm{ng} / 0.3 \mu \mathrm{l})$ were used.

Intracisternal CRH in combination with intra-BNST infusion of $\alpha$-helical $C R H_{9-41}$. The test procedures were similar to those for intracerebroventricular $\mathrm{CRH}$, except that various doses of $\alpha$-helical $\mathrm{CRH}_{9-41}$ $\left(\alpha\right.$-hCRH $\left._{9-41}\right)$ [0 (ACSF), 2, 4, or $6 \mu \mathrm{g}$ total; Peninsula Laboratory] were infused into the BNST 5 min before intracisternal inf usion of CRH $(0.5$ $\mu \mathrm{g})$. The total volume infused into the BNST was $0.3 \mu \mathrm{l} / \mathrm{side}$, and the infusion rate was $0.1 \mu \mathrm{l} / 1 \mathrm{~min}$. All animals were tested four times with each of the $\alpha-\mathrm{hCRH}_{9-41}$ doses. Each test was $48 \mathrm{hr}$ apart, and the injection order was based on a Latin square design. To verify the location of cannulas in the BNST functionally, the animals were tested with intra-BNST infusion of $160 \mathrm{ng}$ of CRH $48 \mathrm{hr}$ after the last intra-BNST $\mathrm{CRH}$ antagonist test session. Again, general procedures for infusion and testing were the same as those used previously.

Intracisternal $\mathrm{CRH}$ in combination with either intracerebroventricular infusion or intra-CeA infusion of $\alpha-h C R H_{9_{-41}}$. The test procedures were similar to those of the intracerebroventricular CRH test, except that either $6 \mu \mathrm{g}$ of $\alpha-\mathrm{hCRH}_{9-41}$ (total) or ACSF was infused bilaterally into the lateral ventricles or the CeA 5 min before intracisternal infusion of $\mathrm{CRH}(0.5 \mu \mathrm{g})$. The total volume infused into the lateral ventricle or the $\mathrm{CeA}$ was $0.3 \mu \mathrm{l} / \mathrm{side}$, and the inf usion rate was $0.1 \mu \mathrm{l} / 1 \mathrm{~min}$. All animals were tested with both $\alpha-\mathrm{hCRH}_{9-41}$ and ACSF infused into the lateral ventricles over two test sessions. Each test was $48 \mathrm{hr}$ apart, and the injection order was counterbalanced.

Potentiated startle training. Two days after their last CRH test, the 
animals received potentiated startle training. The fear-potentiated startle effect, which is blocked by lesions of the amygdala (Campeau and Davis 1995; Sananes and Davis, 1992), was used as a functional test of successful amygdala lesions in the rats previously tested with CRH. On each of 2 consecutive days, the animals were placed in the startle chambers, and after a 5 min acclimation period received 10 light-shock pairings. The conditioned stimulus was a $3700 \mathrm{msec}$ duration, $750 \mathrm{ft}$ lambert light generated by an $8 \mathrm{~W}$ fluorescent bulb, which was attached to the back of the individual chambers. The unconditioned stimulus, a $0.6 \mathrm{~mA}$ foot shock, was generated by five Lehigh Valley SGS-004 constant current shockers located outside of the chamber. Shock intensity was measured using a method described previously (Davis and Astrachan, 1978). The shock was delivered during the last $500 \mathrm{msec}$ of the $3700 \mathrm{msec}$ light at an average ITI of $4 \mathrm{~min}$ (range, 3-5 min). To obtain a measure of how the lesions might have affected reactivity to foot shocks, stabilimeter output during the 10 shocks was sampled for a $200 \mathrm{msec}$ period after the onset of the shock. The mean level of cage output across the 20 foot shocks over the 2 training days was computed for each animal and used as an indicator of shock reactivity. Throughout potentiated startle training, background white noise was $55 \mathrm{~dB}$. The training was performed in the dark, except during light-shock pairing trials.

Potentiated startle testing after lesions of the BNST or amygdala complex. Forty-eight hours after the last potentiated startle training session, the animals were brought into the startle chambers and subjected to a potentiated startle test. After a 5 min acclimation period, $4050-\mathrm{msec}-$ long, $95 \mathrm{~dB}$ startle-eliciting white noise bursts were delivered. These startle noise bursts, called leaders, were used to provide steady, habituated baseline levels of startle before fear-potentiated startle testing. Immediately after the 40 leaders, $2050 \mathrm{msec}$ noise bursts at each of three intensities $(90,95$, and $105 \mathrm{~dB})$ were presented. Half of the stimuli at each of these intensities were presented in darkness (noise alone trials), and the other half were presented $3200 \mathrm{msec}$ after the onset of the light (3700 msec total duration; light noise trial). All startle stimuli were presented in a balanced, irregular order, and the ITI was $30 \mathrm{sec}$. The tests were given in the dark, except during light noise trials, and throughout the test the background white noise was $55 \mathrm{~dB}$.

Potentiated startle testing with intra-CeA $\alpha-h C R H_{9-41}$. The fearpotentiated startle effect, which is blocked by inf usion of local anesthetics into the amygdala, was used as a functional test to evaluate whether $\alpha$-hCRH ${ }_{9-41}$ might have local anesthetic effects. A day after the second fear-potentiated startle-training session, the animals were brought into the startle chambers and 5 min later presented with $20,95 \mathrm{~dB}$ startleeliciting white noise bursts (leaders). After the leaders, three noise alone trials and three light noise trials were presented in a quasirandom order. All startle-eliciting noise bursts were $95 \mathrm{~dB}$. This rather short test was given to match the animals into two subgroups having similar mean potentiated startle levels but minimizing the amount of extinction. The following day, the animals were again brought into the startle chambers and given a fear-potentiated startle test session (PS test 1). Before the test session, however, one of the two subgroups of animals was infused with ACSF $(0.3 \mu l)$, and the remaining group was infused with $\alpha$ hCRH $_{9-41}(6 \mu \mathrm{g}$ in $0.3 \mu \mathrm{l}$ of ACSF). Infusions were made bilaterally into the $\mathrm{CeA}(3 \mu \mathrm{g} / \mathrm{side})$, and the infusion rate was $0.1 \mu \mathrm{l} / 1 \mathrm{~min}$.

Forty-eight hours later, the animals were subjected once more to a fear-potentiated startle test (PS test 2). In this case, animals that received ACSF in PS test 1 were now inf used with $\alpha-\mathrm{hCRH}_{9-41}$ and vice versa. In an effort to make the level of conditioning to the light at the beginning of PS test 2 similar to that before PS test 1 , the animals received a short retraining session (5 light-shock pairings rather than 20 pairings) $24 \mathrm{hr}$ before PS test 2 .

\section{Histology}

At the completion of the studies, the animals were perfused, and their brains were removed and fixed in $30 \%$ sucrose in $10 \%$ formalin solution. Coronal sections $(40 \mu \mathrm{m})$ were cut through the relevant brain areas, and every third section was mounted onto gelatin-coated slides. For verification of cannulation, the sections were stained with cresyl violet. Chemical lesions were verified using the Kluver-Barrera method to assess damage to cell bodies versus fibers of passage separately.

\section{Data analysis}

A predrug startle score was computed by taking the mean of the last 10 startle amplitudes of the predrug test. For each animal, the postdrug startle test scores were blocked by 20 (12 startle score blocks), with the mean score of each block designated as the raw startle score. Throughout the experi-

\section{Table 1. Baseline startle levels before infusion of drugs}

\begin{tabular}{lcc} 
& Pre-ACSF & Pre-CRH \\
\hline Chemical lesion & & \\
Hippocampus & $265 \pm 29$ & $189 \pm 23$ \\
BNST & $254 \pm 38$ & $347 \pm 63$ \\
BLA & $319 \pm 96$ & $333 \pm 66$ \\
CeA & $269 \pm 33$ & $215 \pm 40$ \\
Sham & $228 \pm 49$ & $229 \pm 35$ \\
& & $F_{(4,44)}=1.81 ; p<0.144$
\end{tabular}

\section{Microinfusion}

BNST

$\begin{array}{ll}\mathrm{ACSF} & 335 \pm 48 \\ 40 \mathrm{ng} & \end{array}$

$40 \mathrm{ng}$

$80 \mathrm{ng}$

$160 \mathrm{ng}$

$226 \pm 39$

$283 \pm 44$

$198 \pm 35$

Hippocampus

ACSF $193 \pm 52$

$40 \mathrm{ng}$

$F_{(3,24)}=9.72 ; p<0.001$

$80 \mathrm{ng}$

Intra-BNST antagonist

$\begin{array}{ll}\mathrm{ACSF} & 351 \pm 66 \\ 3 \mu \mathrm{g} & \\ 6 \mu \mathrm{g} & \end{array}$

$6 \mu \mathrm{g}$

Intracerebroventricular antagonist

ACSF $253 \pm 100$

$6 \mu \mathrm{g}$

$235 \pm 51$

$237 \pm 36$

$F_{(2,16)}=0.61 ; p<0.558$

Intra-CeA antagonist

\begin{tabular}{lll}
$\mathrm{ACSF}$ & $185 \pm 36$ & \\
$6 \mu \mathrm{g}$ & & $185 \pm 41$ \\
& $F_{(1,7)}=0.28, p<0.615$ \\
\hline
\end{tabular}

ments, there were no significant differences in the baseline startle levels before any infusion of drugs (Table 1). Therefore, for graphic illustrations of the effect of CRH or ACSF on startle, percent change scores were derived by subtracting the baseline scores from each raw startle score after infusion. These difference scores were then divided by the baseline scores and multiplied by 100 [(post - pre $) /$ pre $\times 100]$.

For statistical evaluations of the drug effects, predrug baseline and mean startle amplitude over the last 120 trials after CRH infusion (last $60 \mathrm{~min}$, trials 121-240) were calculated and compared with predrug baseline and mean startle amplitudes after ACSF infusion using ANOVA. For statistical evaluation of the intra-BNST and intraventral hippocampal CRH infusions on startle, each animal's predrug baseline and mean startle amplitude over the last 120 trials after different doses of CRH infusion were calculated and compared using a one-way ANOVA. BNST and amygdala lesion effects on fear-potentiated startle were assessed by comparing mean startle amplitude in the absence and presence of light combined over the three intensities of startle-eliciting noise bursts using ANOVA. Effects of the CRH antagonist on fear-potentiated startle were also evaluated in the same way using a one-way ANOVA.

\section{RESULTS}

\section{Effects of chemical lesions of the hippocampus, BNST, and amygdala complex on $\mathrm{CRH}-$ enhanced startle and fear-potentiated startle}

Histological verification showed that 10 of the 20 animals had only partial lesions of the BNST, and one animal had a misplaced cannula. Thus, in total, nine animals were included in the data analysis. The center of our ventral hippocampal lesions was aimed 
at the anterior part of this area, which is known to project to the BNST (Cullinan et al., 1993); as a result, the posterior aspect of the ventral hippocampus was consistently spared in all animals. Many of the ventral hippocampus lesioned animals showed bilateral partial lesions $(n=14)$ or unilateral lesions $(n=6)$ and therefore were excluded from the data analysis. An additional eight animals who had an abnormally low baseline startle amplitude ( $<70$ units; $n=5)$ and intracerebroventricular cannula misplacements $(n=3)$ were also excluded. Among the remaining 12 animals that were included in the data analysis, five showed multiple holes in the lesion area, likely attributable to the severity of the lesion. Although verification of these lesions was difficult, the remaining tissue suggested that the area was clearly lesioned, so that their data were included. Seven animals who had complete lesions of the ventral hippocampus without visible damage of passing fibers were also subjected to further data analysis. Seven of the CeA-lesioned animals were excluded from data analysis because of either misplacement of intracerebroventricular cannulas or partial lesions or overly extensive lesions, which encroached on the medial part of the BLA. NMDA lesions of the BLA showed consistent sparing of the most posterior part of the BLA in all animals. Eight of 15 animals showed further sparing of the BLA and therefore were not included in the data analysis. Three sham-lesioned animals were not included in the data analysis because of misplacement $(n=2)$ or loss $(n=1)$ of the cannulas. As a result, the numbers of rats used for data analysis in each group were BNST, 9; ventral hippocampus, 12; CeA, 8; BLA, 7; and sham, 12. Histological reconstructions of the smallest and largest chemical lesions of these areas are illustrated in Figure $1 C$.

Figure 1 shows the effects of intracerebroventricular CRH (Fig. $1 A$ ) or ACSF (Fig. $1 B$ ) on startle amplitude after chemical lesions of the four areas mentioned above. NMDA lesions of the BNST completely blocked CRH-enhanced startle, whereas ibotenic acid lesions of the CeA and NMDA lesions of the BLA or ventral hippocampus failed to do so. Supporting this conclusion, separate $2 \times 2$ ANOVAs using drug (ACSF vs CRH) and time (predrug vs postdrug) as within-subject factors showed that the animals with sham, BLA, CeA, or ventral hippocampus lesions showed a significant drug by time interaction (sham, $F_{(1,11)}=$ 34.335; $p<0.001$; BLA, $F_{(1,6)}=8.24 ; p<0.028$; CeA, $F_{(1,7)}=$ $6.04 ; p<0.044$; and ventral hippocampus, $F_{(1,11)}=5.32 ; p<$ 0.042), indicating that CRH increased startle amplitudes significantly in these animals. On the other hand, animals with BNST lesions failed to show a significant drug by time interaction $\left(F_{(1,8)}\right.$ $=0.00 ; p<0.968)$, indicating blockade of CRH-enhanced startle after the lesions.

In a recent study, we showed that knife cuts of the fimbria/ fornix blocked CRH-enhanced startle, whereas lesions of the dorsal hippocampus did not (Lee and Davis, 1997). Given the fact that the fimbria/fornix is the major output pathway for the hippocampal formation, the failure to block CRH-enhanced startle by either dorsal hippocampal (Lee and Davis, 1997) or ventral hippocampal lesions (current study) is puzzling. Interestingly, although NMDA lesions of the ventral hippocampus overall failed to block CRH-enhanced startle, further investigation of the data revealed that there was a clear dichotomy in lesion effects among ventral hippocampal-lesioned animals. Thus, five animals who had tissue damage in the lesion area, indicative of severe lesions, showed unusually large increases in startle after $\mathrm{CRH}$ (about a 350-400\% increase compared with the typical 150$200 \%$ increase), whereas the other seven animals showed a mean increase in startle amplitude of $<20 \%$ after the CRH infusion. A separate ANOVA using these two subgroups as independent groups showed a significant drug by time by group interaction $\left(F_{(1,10)}=9.51 ; p<0.012\right)$, indicating a difference in the magnitudes of CRH-enhanced startle between these two subgroups (Fig. 2). Thus far, however, we have not been able to determine the critical histological difference between these subgroups.

A previous study showed that large electrolytic lesions of the amygdala blocked CRH-enhanced startle (Liang et al., 1992). It is possible, therefore, that the failure of chemical lesions of either the $\mathrm{CeA}$ or BLA in the present study resulted from inadequate lesions. To test this, the animals with lesions of the BLA, CeA, or BNST were trained and tested for fear-potentiated startle, which is known to be blocked by chemical lesions of either the CeA (Campeau and Davis, 1995) or the BLA (Sananes and Davis, 1992). Figure 3 shows that lesions of the CeA and the BLA, but not the BNST, completely blocked fear-potentiated startle. An overall ANOVA showed that the main trial type effect was significant (noise alone vs light-noise, $F_{(1,26)}=19.27 ; p<0.001$ ), whereas the main group effect was not $\left(F_{(3,26)}=1.60 ; p<0.214\right)$. More importantly, however, there was a significant two-way interaction between lesion and trial type $\left(F_{(3,26)}=5.39 ; p<0.005\right)$. A post hoc test using Tukey's multiple comparisons showed that the magnitude of fear-potentiated startle was significantly greater in the sham-lesioned animals compared with the BLA-lesioned $(p<0.019)$ or the CeA-lesioned animals $(p<0.018)$ but not with the BNST-lesioned animals $(p<0.776)$. These results were not attributable to differences in sensitivity to foot shocks after chemical lesions, because a comparison of shock reactivity among the BLA, CeA, BNST, and sham lesion groups showed no significant difference in reactivity to foot shocks after lesions. Taken together, NMDA lesions of the BNST, which successfully blocked $\mathrm{CRH}$-enhanced startle, did not have any effect on fearpotentiated startle, whereas chemical lesions of the BLA or the CeA completely blocked fear-potentiated startle but had no effect on CRH-enhanced startle.

\section{Effects of intra-BNST and intra-hippocampus (anterior) infusions of CRH on startle}

Nine of the 10 intra-BNST animals showed proper locations of the cannula tips and were subjected to data analysis. The anterior part of the ventral hippocampus was substantially more difficult to cannulate, and only 9 of 15 animals had cannula tips located inside of the hippocampus bilaterally. Figure $4 B$ shows the composites of the bilateral BNST and the ventral hippocampus cannula placements.

Intra-BNST infusion of CRH increased startle amplitude in a dose-dependent manner. Although the magnitude of increasing startle amplitude after intra-BNST CRH was not as large as that induced by intracerebroventricular $\mathrm{CRH}(70 \%$ increase from baseline vs $>100 \%$ increase from baseline), the onset of the $\mathrm{CRH}$ effect was immediate, as expected if the BNST is a primary receptor site. In contrast, there is a $20-30$ min delay in the onset of CRH-enhanced startle after intracerebroventricular infusions. If this delay reflects the time required for $\mathrm{CRH}$ to diff use into a primary receptor site, direct infusion of $\mathrm{CRH}$ into the receptor site should elicit its effect without any delay. Furthermore, although intra-BNST CRH increased startle significantly during the first $60 \mathrm{~min}$ after infusion $\left(F_{(3,24)}=3.21 ; p=0.041\right)$, the excitatory effect of $\mathrm{CRH}$ on startle was larger and more stable throughout the second hour of the test session, similar to characteristics of intracerebroventricular CRH-enhanced startle.

In contrast, $\mathrm{CRH}$ inf used into the ventral hippocampus did not 
A

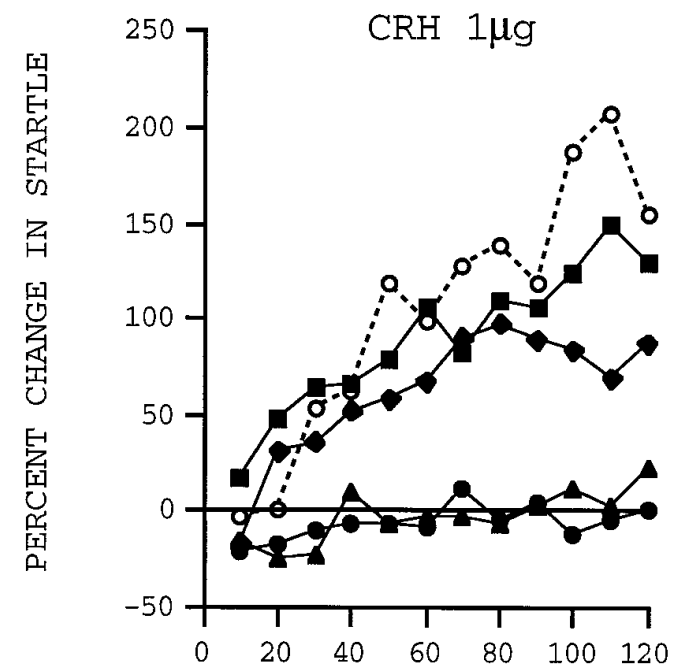

B

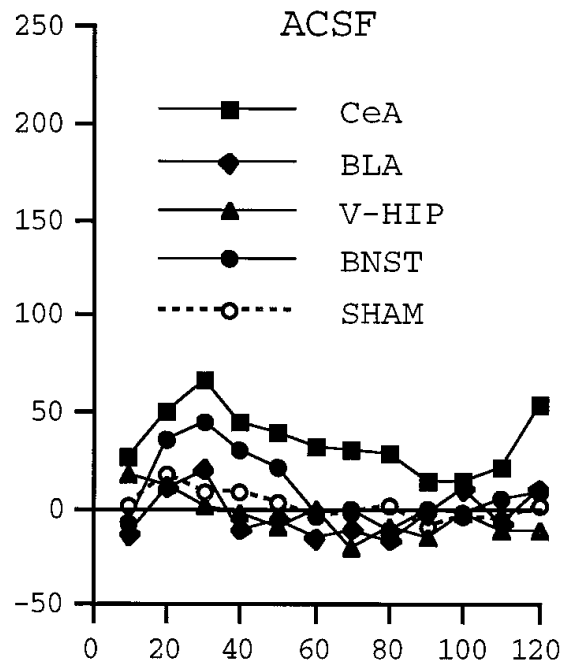

MINUTES AFTER INFUSION

C V. Hippocampus

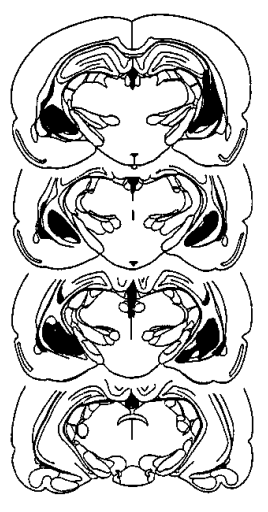

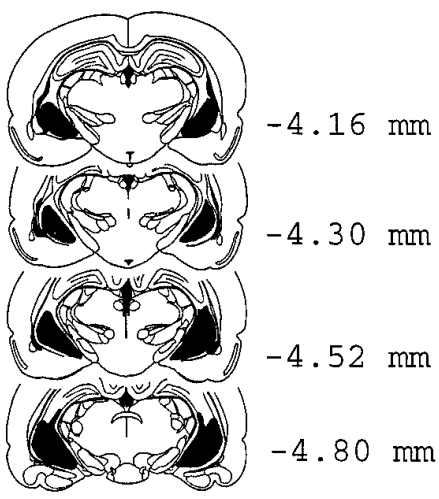

BNST

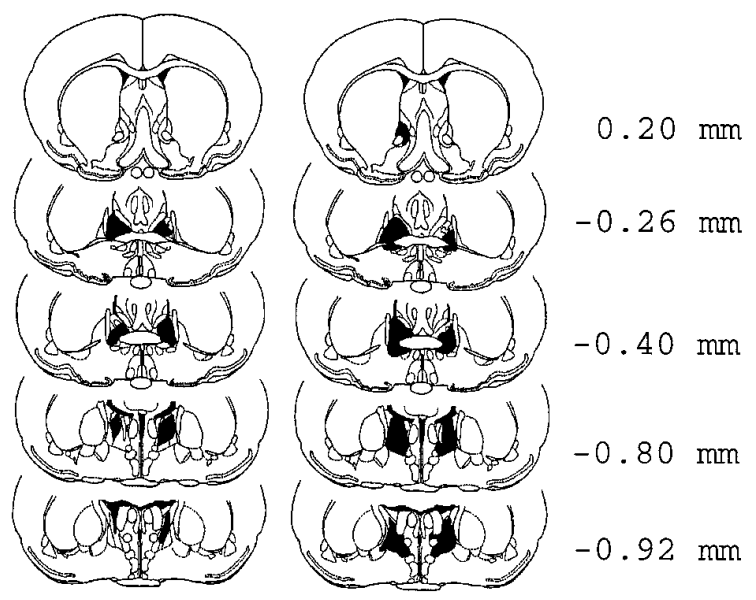

$\mathrm{CeA}$

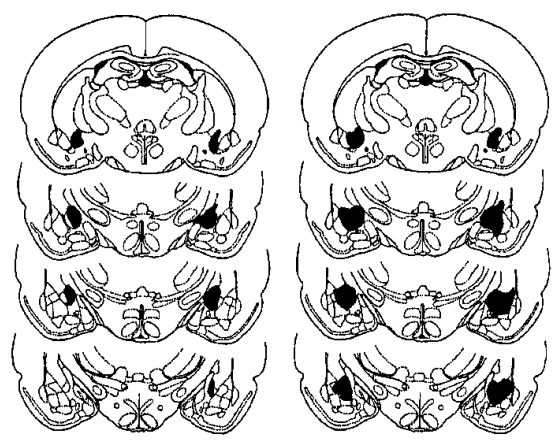

BLA
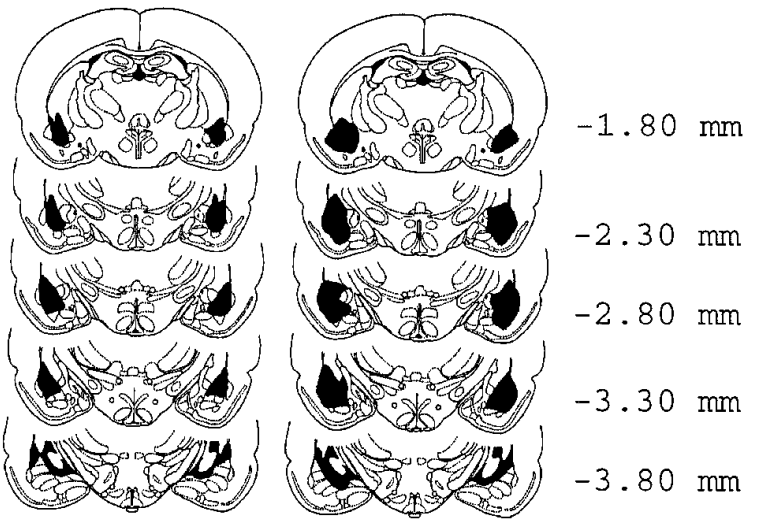

Figure 1. Effects of sham lesions and chemical lesions of the bed nucleus of the stria terminalis, ventral hippocampus, and central or basolateral nucleus of the amygdala on mean percent change of startle amplitude after intracerebroventricular infusion of $1 \mu \mathrm{g}$ of CRH $(A)$ or ACSF $(B)$. Each data point represents the mean percent change of 20 postdrug test trials. $C$, Smallest (left) and largest (right) lesions of these areas. 


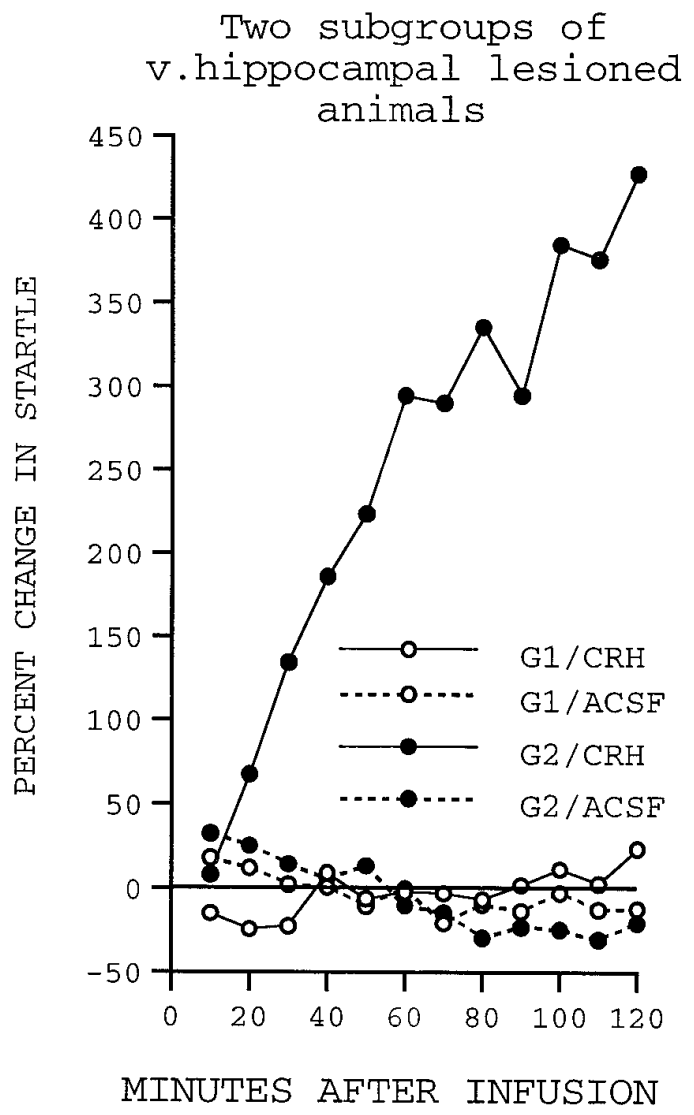

Figure 2. Mean percent change of startle amplitude after intracerebroventricular infusion of $1 \mu \mathrm{g}$ of CRH or ACSF. The open circles show the behavioral data of the animals that had a blockade of CRH-enhanced startle after NMDA lesions of the ventral hippocampus [group 1 (G1)], and the closed circles show the behavioral data of the animals that had super CRH-enhanced startle after lesions [Group $2(G 2)$ ]. Notice the difference in the scale.

show significantly different effects on startle compared with ACSF infusion. Both CRH and ACSF increased startle somewhat over the first $40 \mathrm{~min}$ of the test period but did not have any effects on startle for the remaining $80 \mathrm{~min}$ of the test session. The nonspecific and transient nature of this excitatory effect may be attributable to mechanical excitation after pressure injections.

An ANOVA on the effects of CRH after intra-BNST inf usions showed significant dose $\left(F_{(3,24)}=2.99 ; p<0.05\right)$, and time main effects (predrug baseline vs postdrug, $F_{(1,8)}=7.275 ; p<0.027$ ) and a significant time by dose interaction $\left(F_{(3,24)}=6.52 ; p<\right.$ $0.002)$. The main infusion order effect was not significant $(p<$ 0.235 ), suggesting that the infusion sequence of the different doses was not a determining factor for the significant dose effect. Subsequent tests, using Dunnett's multiple comparisons, showed that there were significant differences in startle amplitudes after both $80 \mathrm{ng}\left(t_{(8)}=4.72 ; p<0.01\right)$ and $160 \mathrm{ng}\left(t_{(8)}=4.87 ; p<0.01\right)$ $\mathrm{CRH}$ inf usions compared with inf usion of ACSF. The difference in startle amplitudes after ACSF and $40 \mathrm{ng} \mathrm{CRH}$ infusions was not significant $(p>0.05)$.

In contrast, intraventral hippocampus infusions of neither ACSF nor different doses of CRH induced significant changes in startle amplitude through the second hour of the test sessions $(p>0.05)$. However, analysis based on the data from the first 60 min of the test session showed a significant main time effect (preinfusion vs postinf usion, $F_{(1,8)}=10.24 ; p<0.013$ ) without a

\section{Fear potentiated startle}

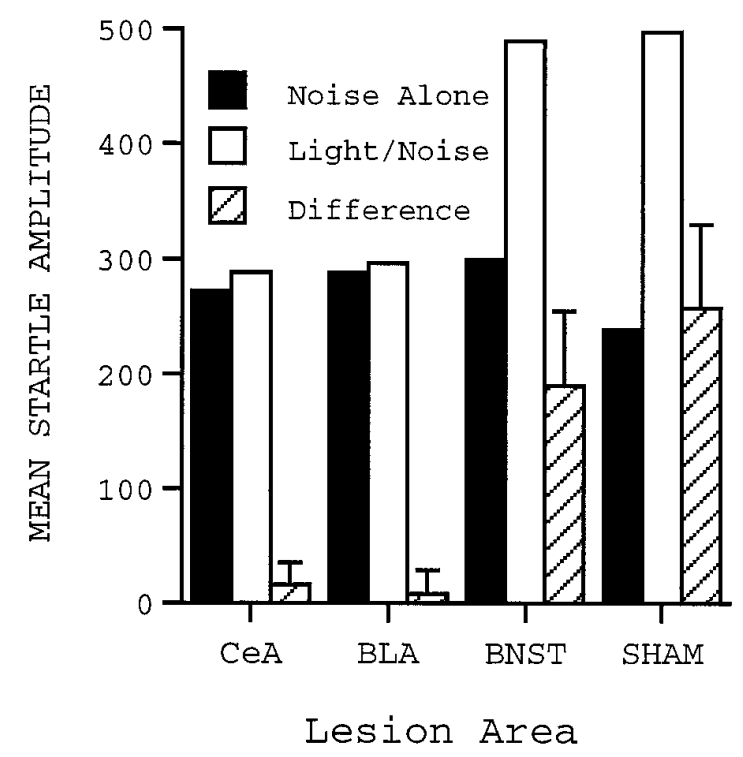

Figure 3. Effects of sham lesions and NMDA lesions of the bed nucleus of the stria terminalis and central or basolateral nucleus of the amygdala on fear-potentiated startle. Each bar represents the mean startle amplitude over 30 noise alone trials (10 of each at 90, 95, and $105 \mathrm{~dB}$; black bars) or 30 light noise trials (10 of each at 90,95 , and $105 \mathrm{~dB}$ noise in the presence of light; white bars). The difference (hatched bars) between the noise and light noise trials indicates the magnitude of fear-potentiated startle.

significant main dose effect $(p<0.570)$ or a significant interaction between dose and time $(p<0.557)$, indicating that intraventral hippocampus infusion of $\mathrm{CRH}$ induced no dose-related changes in startle amplitude. Figure $4 A$ shows a summary of the behavioral data after intra-BNST and intraventral hippocampus infusions of ACSF and CRH.

\section{Effects of intra-BNST infusions of $\alpha-\mathrm{hCRH}_{9-41}$ on CRH-enhanced startle}

Three of 10 animals were not included in the data analysis because of death $(n=1)$, loss of cannula $(n=1)$, and cannula misplacement $(n=1)$. Figure $5 C$ illustrates a composite of the BNST cannula placements.

Figure $5 A$ shows that intra-BNST infusions of $\alpha$-hCRH ${ }_{9-41}$ attenuated the effect of $0.5 \mu \mathrm{g}$ of $\mathrm{CRH}$ infused into the fourth ventricle in a dose-dependent manner. This conclusion was confirmed by an overall ANOVA that yield a significant main time effect (pre- vs post-CRH inf usion, $F_{(2,12)}=16.85 ; p<0.006$ ) and a significant time by dose interaction $\left(F_{(2,12)}=5.12 ; p<0.025\right)$. A post hoc test, using Dunnett's multiple comparisons, showed that the magnitudes of CRH-enhanced startle were not different when ACSF or $3 \mu \mathrm{g}$ of $\alpha$-hCRH${ }_{9-41}$ were inf used into the BNST concomitantly with intracisternal infusion of $\mathrm{CRH}\left(t_{(6)}=2.04\right.$; $p>0.05)$. However, the magnitude of CRH-enhanced startle was significantly reduced when $6 \mu \mathrm{g}$ of $\alpha-\mathrm{hCRH}_{9-41}$, compared with ACSF, was infused into the BNST concomitantly with intracisternal CRH $\left(t_{(6)}=3.15 ; p<0.05\right)$. Furthermore, the dosedependent reduction of the $\mathrm{CRH}$ effect by the $\mathrm{CRH}$ antagonist was not due to the particular infusion order of the antagonist, because there was no main infusion order effect $(p<0.327)$.

In addition, the cannula placements in the BNST in the antagonist study appeared to be directed toward functionally relevant 
A

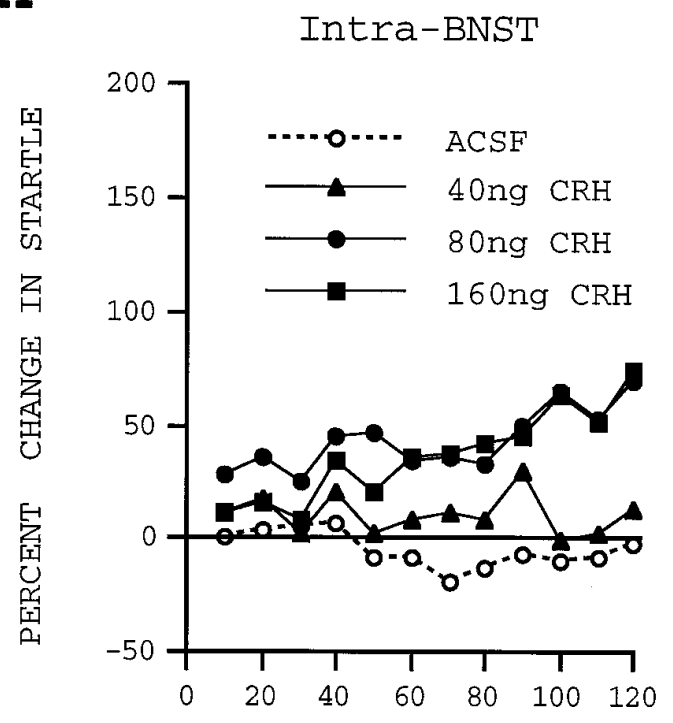

B

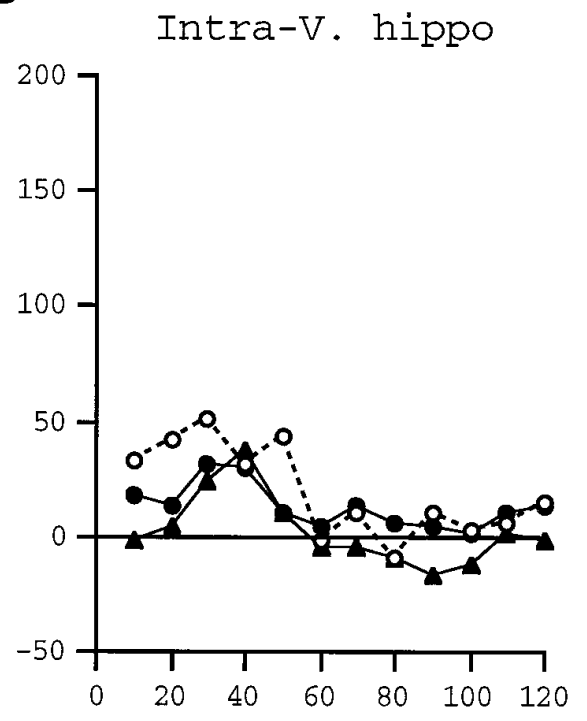

\section{MINUTES AFTER INFUSION}

C BNST

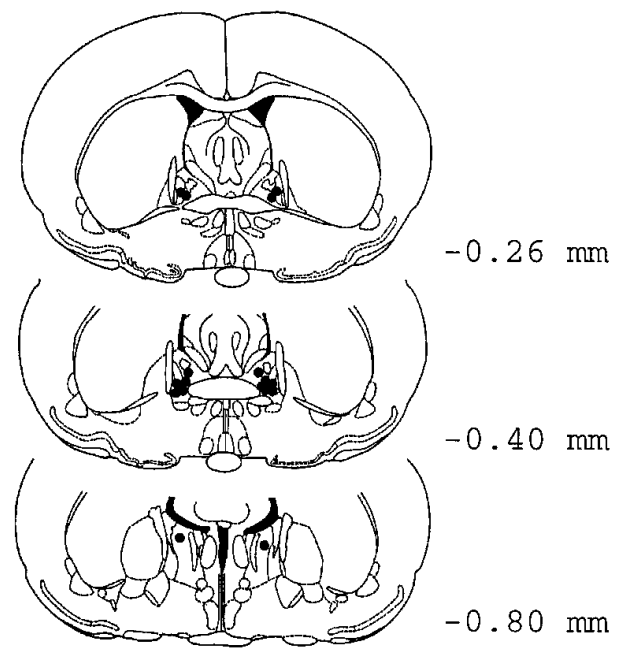

V. Hippocampus

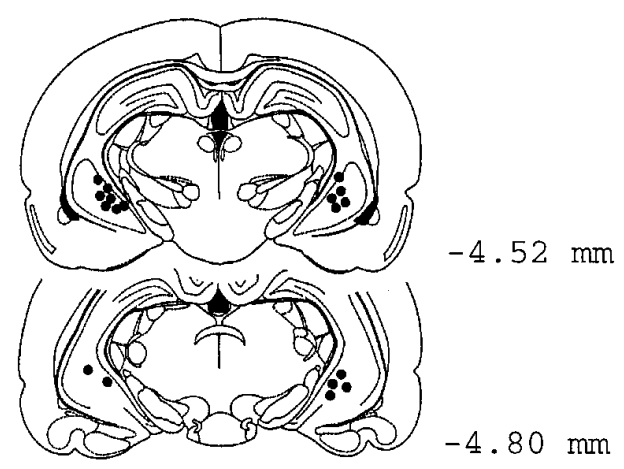

Figure 4. Effects of various doses of CRH infused into the bed nucleus of the stria terminalis $(A)$ or the ventral hippocampus $(B)$, on mean percent change of startle amplitude. Each data point represents the mean percent change of 20 postdrug test trials. $C$, Histological reconstructions showing placements of cannula tips of the animals included in the data analysis.

sites for the excitatory effect of $\mathrm{CRH}$ on startle, because a subsequent infusion of $160 \mathrm{ng} \mathrm{CRH}$ into the same sites increased startle amplitude significantly $\left(t_{(5)}=3.90 ; p<0.011\right)$ (Fig. $\left.5 B\right)$. Indeed, in these animals ( $n=6$; one animal was excluded in this experiment because of loss of the cannula after the antagonist study), the magnitude of the increase in startle was comparable to that found after intracerebroventricular infusion of a much higher amount of CRH.

\section{Effects of intracerebroventricular infusion of $6 \mu \mathrm{g}$ of $\alpha-\mathrm{hCRH}_{\mathbf{9 - 4 1}}$ on CRH-enhanced startle}

The BNST is located immediately ventral to the lateral ventricles. Therefore, one could argue that the blockade seen with intra-
BNST infusion of $\alpha$-hCRH ${ }_{9-41}$ resulted from leakage of the antagonist into the lateral ventricles. Therefore, to be certain that leakage into the ventricle could not explain the intra-BNST antagonist effect, $6 \mu \mathrm{g}$ of $\alpha-\mathrm{hCRH}_{9-41}$ was infused intentionally into the lateral ventricle in combination with intracisternal infusion of $0.5 \mu \mathrm{g}$ of CRH. All seven animals showed correct cannula placements (bilateral lateral ventricle and unilateral fourth ventricle) and were therefore included in the data analysis.

Figure 6 shows that $6 \mu \mathrm{g}$ of $\alpha-\mathrm{hCRH}_{9-41}$ infused into the lateral ventricles did not block the effect of $0.5 \mu \mathrm{g}$ of $\mathrm{CRH}$ given intracisternally on startle. In fact, if anything, the CRH effect seemed even larger after this dose of the antagonist. An overall 
A

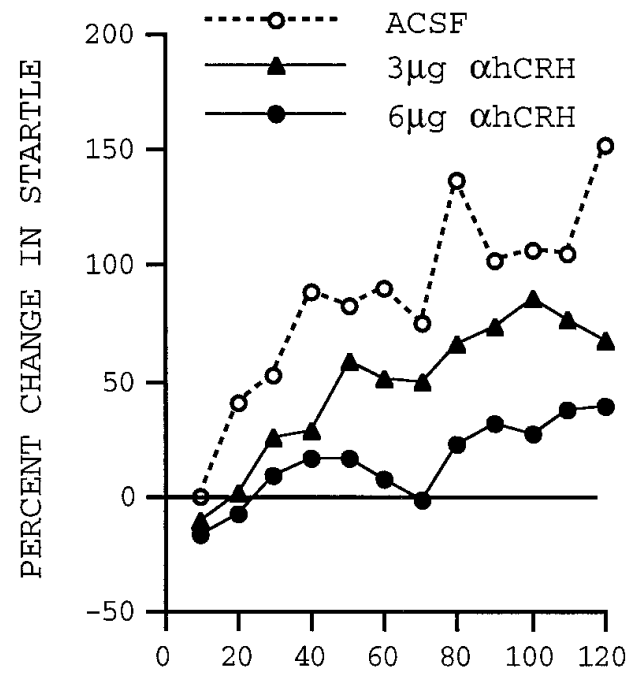

Intra-BNST $\alpha h \mathrm{CRH}$ with i.c. $\mathrm{CRH}$
B

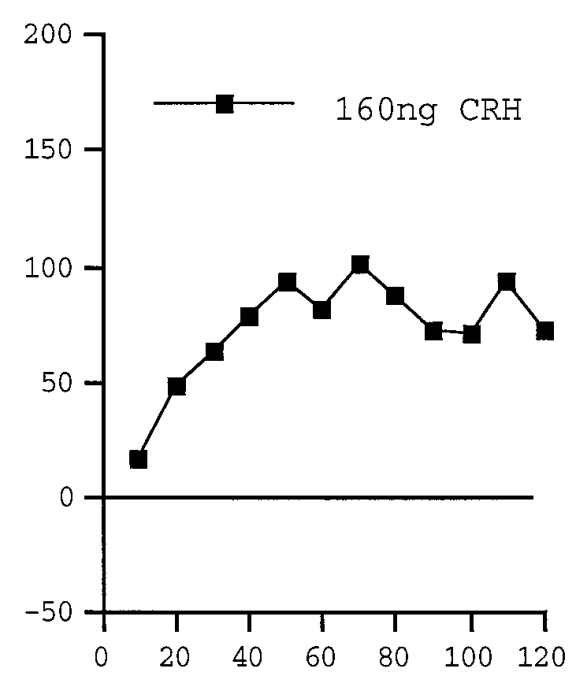

MINUTES AFTER INFUSION

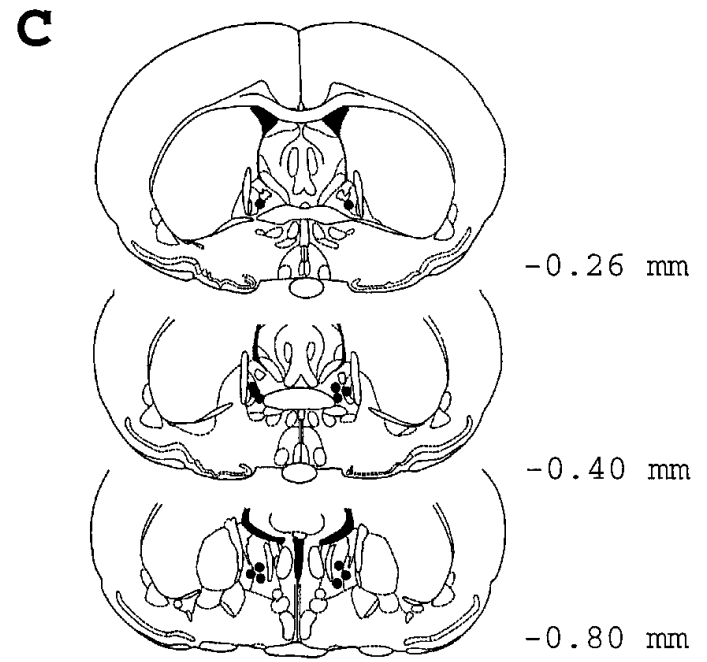

Figure 5. A, Mean percent change of startle amplitude after fourth ventricle infusion of 0.5 $\mu \mathrm{g}$ of CRH into rats pretreated 5 min earlier with various doses of the $\mathrm{CRH}$ antagonist into the BNST. The same rats were subsequently tested with intra-BNST infusion of $160 \mathrm{ng}$ of $\mathrm{CRH}$, and the behavioral data are shown in $B$. Each data point represents the mean percent change of 20 postdrug test trials. i.c., Intracisternal. C, Histological reconstructions showing placements of intra-BNST cannula tips of the animals included in the data analysis.

ANOVA revealed that there was a main effect of time, reflecting the pretreatment to posttreatment increase in startle amplitudes after $\mathrm{CRH}$ infusion $\left(F_{(1,6)}=9.18 ; p<0.023\right)$ but no main antagonist effect $\left(F_{(1,6)}=0.57 ; p<0.478\right)$ or time by antagonist interaction $\left(F_{(1,6)}=1.03 ; p<0.349\right)$. Thus, intracisternal infusion of $0.5 \mu \mathrm{g}$ of $\mathrm{CRH}$ increased startle amplitude significantly, regardless of whether ACSF or $\alpha-\mathrm{hCRH}_{9-41}$ was concomitantly infused into the lateral ventricles. This makes it highly unlikely that the blockade of $\mathrm{CRH}$-enhanced startle seen with the same dose of $\alpha-\mathrm{hCRH}_{9-41}$ inf used locally into the BNST resulted from leakage of the $\mathrm{CRH}$ antagonist into the lateral ventricles located just dorsal to the BNST infusion sites.

\section{Effects of intra-CeA infusion of $6 \mu \mathrm{g}$ of $\alpha-\mathrm{hCRH}_{9-41}$ on $\mathrm{CRH}-\mathrm{enhanced}$ startle and expression of fear- potentiated startle}

In the first part of the present experiment, $\alpha-\mathrm{hCRH}_{9-41}$ was infused into the $\mathrm{CeA}$ concomitantly with intracisternal $\mathrm{CRH}$ to examine the anatomical specificity of the blockade of $\mathrm{CRH}$ enhanced startle seen with intra-BNST inf usions of $\alpha-\mathrm{hCRH}_{9-41}$. Two of 10 animals were excluded because of cannula misplacements. Figure $7 C$, left panel, illustrates a composite of cannula locations within the CeA.

Figure $7 A$ showed that $6 \mu \mathrm{g}$ of $\alpha-\mathrm{hCRH}_{9-41}$ infused into the $\mathrm{CeA}$ did not block the excitatory effect of $0.5 \mu \mathrm{g} \mathrm{CRH}$ given intracisternally on startle. An overall ANOVA revealed a significant main effect of time $\left(F_{(1,7)}=11.94 ; p<0.011\right)$, indicative of the excitatory effect of $\mathrm{CRH}$, but neither a main antagonist effect $\left(F_{(1,7)}=0.01 ; p<0.944\right)$ nor a time by antagonist interaction $\left(F_{(1,7)}=0.53 ; p<0.489\right)$. These data suggest that $\mathrm{CRH}$ receptors in the amygdala are not a part of the neural circuitry used by $\mathrm{CRH}$ given intracerebroventricularly, whereas $\mathrm{CRH}$ receptors in the BNST are critically involved in mediating CRH-enhanced startle.

In the second part of the present experiment, the possibility that nonspecific effects of the antagonist (i.e., local anesthetic 


\section{I.C. CRH}

with i.C.V. $\alpha$ hCRH

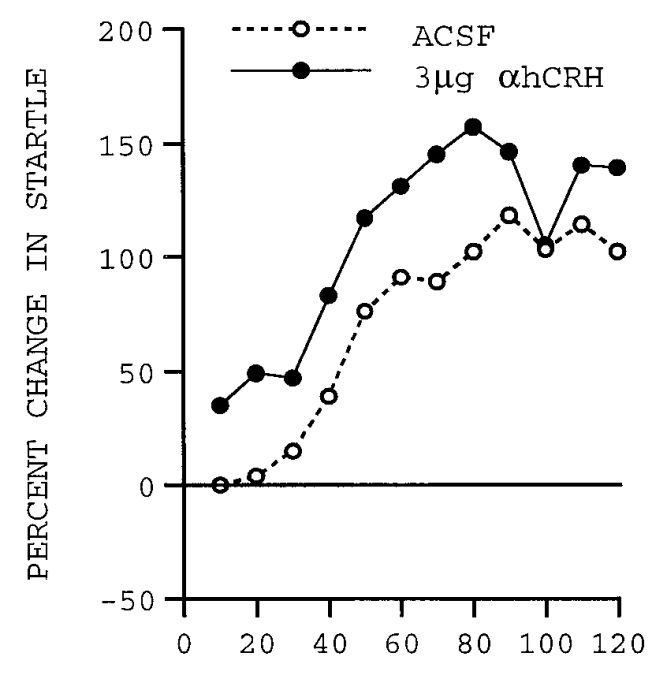

\section{MINUTES AFTER INFUSION}

Figure 6. Mean percent change of startle amplitude after fourth ventricle infusion of $0.5 \mu \mathrm{g}$ of CRH into rats pretreated 5 min earlier with $6 \mu \mathrm{g}$ of the $\mathrm{CRH}$ antagonist into the lateral ventricles. Each data point represents the mean percent change of 20 postdrug test trials. I.c., Intracisternal; i.c.v., intracerebroventricular.

effects) may have caused the blockade of intracisternal CRH was investigated. Because NMDA lesions of the BNST block CRHenhanced startle, one could argue that $\alpha-\mathrm{hCRH}_{9-41}$ infused into the BNST blocked the intracisternal CRH effect not by pharmacological antagonism but by causing reversible inactivation of the BNST. Hence, after the main experiment looking at the effects of $\alpha-\mathrm{hCRH}_{9-41}$ infused into the amygdala on intracisternal CRH, the same rats were trained and then tested for fear-potentiated startle after infusion of $6 \mu \mathrm{g}$ of $\alpha-\mathrm{hCRH}_{9-41}$ into the CeA. It is well known that the $\mathrm{CeA}$ is essential for the expression of fear-potentiated startle (Hitchcock and Davis, 1986, 1987; Campeau et al., 1992). Therefore, if $6 \mu \mathrm{g}$ of $\alpha-\mathrm{hCRH}_{9-41}$ did cause a local anesthetic effect, it should block the expression of fearpotentiated startle. To test this, $48 \mathrm{hr}$ after the last $\mathrm{CRH}-\alpha-$ $\mathrm{hCRH}_{9-41}$ test, the same animals were trained, and $2 \mathrm{~d}$ later the level of fear-potentiated startle was tested after intra-CeA infusion of either ACSF or $6 \mu \mathrm{g}$ of $\alpha-\mathrm{hCRH}_{9-41}$, using a crossover design. Figure $7 B$ shows that ACSF or $6 \mu \mathrm{g}$ of $\alpha-\mathrm{hCRH}_{9-41}$ infused into the $\mathrm{CeA}$ failed to block the expression of fearpotentiated startle. Thus, an overall ANOVA showed a highly significant increase in startle in the presence versus absence of the light (fear-potentiated startle, $F_{(1,7)}=23.40 ; p<0.001$ ) but no interaction between the fear-potentiated startle effect and the antagonist effect $\left(F_{(1,7)}=3.30 ; p<0.119\right)$. The present study provides the first evidence demonstrating that $\mathrm{CRH}$ in the $\mathrm{CeA}$ may not be involved in the expression of fear-potentiated startle. More importantly, because the functional integrity of the CeA is critical in expressing fear-potentiated startle, and because infusion of local anesthetics into the amygdala blocks the expression of conditioned fear (Helmstetter, 1994), including fearpotentiated startle (J. M. Hitchcock and M. Davis, unpublished observation), making the reasonable assumption that the putative local anesthetic effects of compounds will be similar in different brain areas, these data suggest that $\alpha-\mathrm{hCRH}_{9-41}$ does not have local anesthetic effects at a $6 \mu \mathrm{g}$ dose.

\section{DISCUSSION \\ The BNST may be a primary receptor site for CRH given intracerebroventricularly}

The present studies strongly suggest that the BNST might be a primary receptor site for the excitatory effect of intracerebroventricular $\mathrm{CRH}$ on the acoustic startle reflex. NMDA lesions of the BNST blocked CRH-enhanced startle. Intra-BNST infusions of $\mathrm{CRH}$ significantly increased startle amplitude, and a CRH antagonist, $\alpha-\mathrm{hCRH}_{9-41}$, dose-dependently blocked CRH-enhanced startle.

The role of the hippocampus in CRH-enhanced startle is unclear. Because our ventral hippocampal lesions aimed to damage the anterior part of the ventral hippocampal/subiculum area, which projects directly into the BNST (Cullinan et al., 1993), the posterior aspect of this area was consistently spared. Therefore, it is clear that the effects of whole hippocampal or complete ventral hippocampal lesions need to be examined. At the present time, neither lesions of the dorsal hippocampus (Lee and Davis, 1997) nor those of the ventral hippocampus (present study) blocked $\mathrm{CRH}$-enhanced startle. However, a subset of the ventral hippocampus-lesioned animals showed almost complete blockade of CRH-enhanced startle, whereas animals with seemingly more severe damage showed robust CRH-enhanced startle. Although we have replicated this effect, we have no further information to explain the differences between these two subgroups. Lesion studies accompanied by various counterstaining methods for different neurotransmitters (e.g., GABA and acetylcholine) are clearly needed. Because intraventral hippocampal infusions of $\mathrm{CRH}$ did not enhance startle, we predict that the hippocampus may play a modulatory role for CRH-enhanced startle rather than being a primary receptor site.

The finding that large electrolytic lesions of the amygdala blocked CRH-enhanced startle (Liang et al., 1992) is still not resolved by the present data. Our suspicion is that the electrolytic lesions destroyed fibers projecting from the BNST to the startle pathway. Further studies using electrolytic lesions in combination with retrograde or anterograde tracing techniques will be required to address this issue.

\section{Implications for a possible distinction between fear and anxiety}

Intracerebroventricular infusion of CRH elicits a pattern of behavioral changes typically observed during states of fear or anxiety (cf. Dunn and Berridge, 1990). Although there is a close correspondence between these two emotional states, they also differ in important ways. Fear is a natural, adaptive change elicited by a potentially threatening stimulus, which prepares an animal to cope with provocation. Fear generally is elicited by an identifiable stimulus and subsides shortly after its offset. Anxiety also is a change in state that has many of the same signs and symptoms of fear. However, it may not be clearly associated with a single eliciting stimulus, may last for long periods once activated, and may lack clear adaptive significance.

Defined in this way, fear-potentiated startle clearly represents a measure of conditioned fear, because it is rapidly produced by a definable stimulus and dissipates quickly once that stimulus is turned off. On the other hand, CRH-enhanced startle may be 
A

$$
\begin{aligned}
& \text { I.c. CRH with } \\
& \text { intra-CeA. } \alpha \text { hCRH }
\end{aligned}
$$

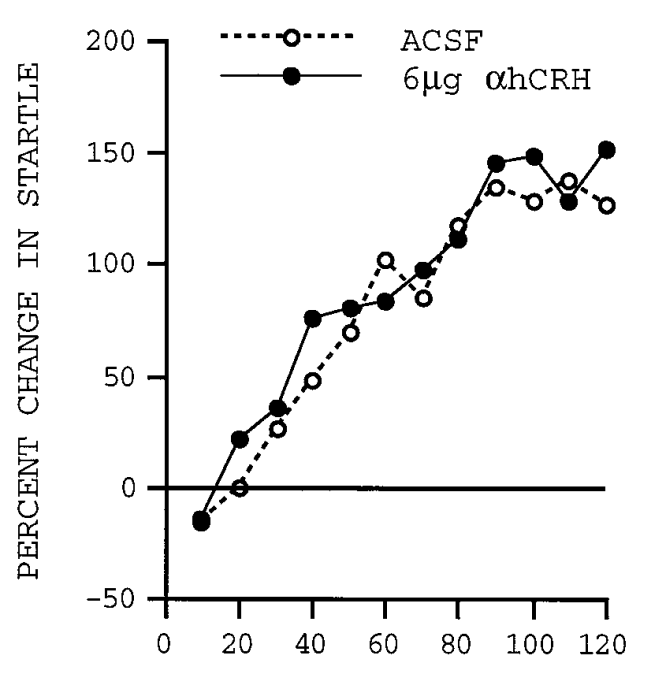

MINUTES AFTER INFUSION

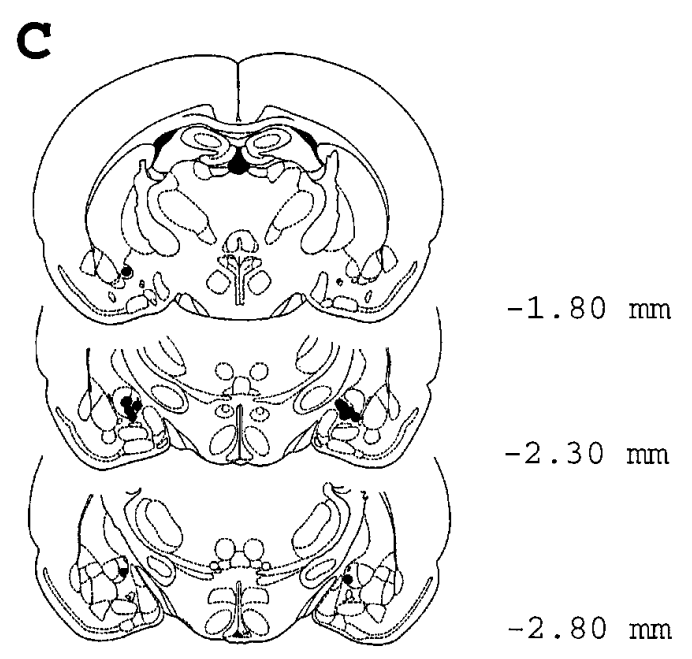

more akin to anxiety, because it has a more gradual onset and lasts for a very long time.

The present studies found a double dissociation between the amygdala and BNST with respect to fear-potentiated and CRHenhanced startle. Lesions of the BNST, but not the CeA or BLA, completely blocked CRH-enhanced startle. Conversely, the same lesions of the BNST did not block fear-potentiated startle, whereas lesions of the CeA or BLA did. Moreover, $\alpha-\mathrm{hCRH}_{9-41}$ infused into the BNST, but not into the CeA, significantly attenuated $\mathrm{CRH}$-enhanced startle, consistent with the idea that only receptors in the BNST are involved in CRH-enhanced startle. If one agrees that $\mathrm{CRH}-e n h a n c e d$ startle is a measure of anxiety, whereas fear-potentiated startle is a measure of fear, the present results suggest that the BNST may be a neural substrate related to anxiety states, whereas the amygdala may be critical for fear responses.

\section{B \\ Intra-CeA $\alpha h \mathrm{CRH}$ on potentiated startle}

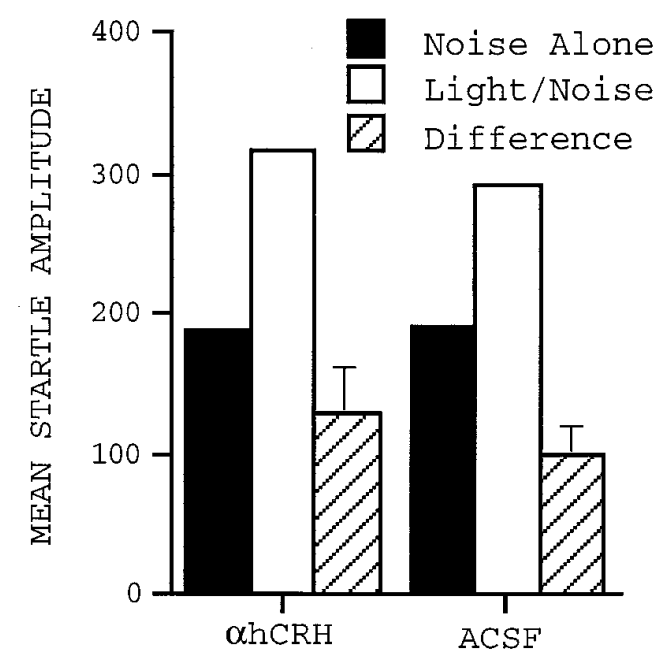

Figure 7. $A$, Mean percent change of startle amplitude after fourth ventricle infusion of $0.5 \mu \mathrm{g}$ CRH into rats pretreated $5 \mathrm{~min}$ earlier with $6 \mu \mathrm{g}$ of the $\mathrm{CRH}$ antagonist into the CeA. Each data point represents mean percent change of 20 postdrug test trials. I.c., Intracisternal. B, Effects of ACSF or $6 \mu \mathrm{g}$ of the CRH antagonist infused into the $\mathrm{CeA}$ on expression of fear-potentiated startle. Each bar represents the mean startle amplitude over 30 noise alone trials $(10$ of each at 90,95 , and $105 \mathrm{~dB}$; black bars) or 30 light noise trials (10 of each at 90, 95, and $105 \mathrm{~dB}$ noise in the presence of light; white bars). The difference (hatched bars) between the noise and light noise trials indicates the magnitude of fear-potentiated startle. $C$, Histological reconstructions showing placements of intra-CeA cannula tips of the animals included in the data analysis.

Supporting this hypothesis, Möller et al. (1994) reported that c-fos antisense infused into the amygdala failed to block intracerebroventricular CRH-induced suppression of punished responses, suggesting that the amygdala may not mediate anxiogenic effects induced by intracerebroventricular $\mathrm{CRH}$. Walker and Davis (1996) found that blockade of glutamate receptors in the BNST, but not in the CeA, blocked the unconditioned anxiogenic effects of a bright light $(20 \mathrm{~min}$ duration), which produces a slowly developing increase in startle amplitude that lasts for a long time once the light is turned off (Walker and Davis, 1997). Davis et al. (1995) showed that electrolytic lesions of the BNST blocked contextual conditioning or long-term sensitization of startle when fear-potentiated startle training occurred daily but had no effect on fear-potentiated startle itself. Gray et al. (1993) reported that lesions of the BNST attenuated increases in 
plasma levels of ACTH and corticosterone after reintroduction into a context previously paired with foot shocks.

The hypothesis that the BNST may be a neural substrate related to anxiety, however, should not be taken as contradictory to a wealth of evidence pointing to the critical role of the amygdala in various stress and anxiety responses. Stress, including intracerebroventricular infusion of $\mathrm{CRH}$, induces strong c-fos activation within the amygdala (Arnold et al., 1992; Honkaniemi, 1992; Honkaniemi et al., 1992; Imaki et al., 1993), along with increased CRH mRNA (Swanson and Simmons, 1989; Mamalaki et al., 1992; Makino et al., 1994a,b, 1995). Furthermore, CRH is released in the amygdala after restraint stress (Pich et al., 1995).

Similar to intracerebroventricular CRH effects, intra-amygdala infusion of $\mathrm{CRH}$ has been reported to produce anxiogenic behavior (Liang and Lee, 1988; Lee and Tasi, 1989; Elkabir et al., 1990), and a CRH antagonist infused into the amygdala significantly attenuated stress-induced freezing (Heinrichs et al., 1992; Swiergiel et al., 1993) or anxiogenic effects of alcohol withdrawal (Rassnick et al., 1993; Menzaghi et al., 1994).

The BNST is a primary target of the amygdala (de Olmos et al., 1985; Sun et al., 1991; Alheid et al., 1995), and both the BNST and the amygdala share almost identical brainstem target areas implicated in stress and anxiety responses (Schwaber et al., 1980; Takeuchi et al., 1982, 1983; Sofroniew, 1983; Swanson et al., 1984; Veening et al., 1984; Holstege et al., 1985; Gray and Magnuson, 1987, 1992; Moga et al., 1989). Interestingly, some of the projections to the amygdala (cf. Gray, 1993) and the projections from the amygdala to the BNST contain CRH (Sakanaka et al., 1986; Gray, 1990). Therefore, together with finding that CRH neurons in the amygdala can be activated by CRH (Uryu et al., 1992), one can hypothesize that stress may induce release of $\mathrm{CRH}$ in the amygdala, which then releases CRH in the BNST. Activation of the BNST by CRH would activate various brainstem target areas involved in stress and anxiety responses. This would explain why lesions of the BNST but not the amygdala blocked effects of $\mathrm{CRH}$ given intracerebroventricularly (present study), whereas amygdala manipulations are effective in blocking stress and anxiety responses caused by various stressors. If the BNST is indeed the final common pathway for stress and anxiety responses, one would predict that lesions of the BNST or a CRH antagonist infused into the BNST would block various stress and anxiety responses as effectively as these same treatments do when applied to the amygdala.

\section{Clinical implications}

Patients with post-traumatic stress disorder (PTSD) or depression often show elevated CSF concentrations of CRH (Nemeroff et al., 1984; France et al., 1988; Arató et al., 1989; Bánki et al., 1992a,b; Darnell et al., 1994). However, neither the origin nor the function of this elevated CSF CRH is known. The present studies provide evidence that CSF CRH may play an active role in CNS functions via interacting with the BNST.

If CSF CRH activates the BNST, which in turn chronically activates its target areas critical for stress and anxiety responses (see above), this may be responsible for enhanced anxiety observed in many of these patients. As one of the biological models of PTSD and depression predicts (cf. Post et al., 1981; Charney et al., 1993), such effects might be amplified by stress-induced kindling of various limbic areas, including the amygdala and BNST. The amygdala and BNST show particularly dense concentrations of CRH cell bodies and receptors (Cummings et al., 1983; De Souza et al., 1984; Sawchenko and Swanson, 1985; Sakanaka et al., 1987; Chalmers et al., 1995; Lovenberg et al., 1995), and chronic stress increased CRH mRNA in the CeA and BNST (Mamalaki et al., 1992; Makino et al., 1994a,b, 1995). Taken together, these data raise the possibility that stress may sensitize CRH systems in limbic structures, such as the amygdala and/or BNST, leading to a persistent increase in CRH transmission. If so, nonpeptide $\mathrm{CRH}$ antagonists could have major prophylactic effects in halting the spiral of stress-induced sensitization of limbic circuits. The present results would suggest that $\mathrm{CRH}$ antagonists that selectively bind to $\mathrm{CRH}$ receptors in the BNST may be especially promising in this regard.

\section{REFERENCES}

Alheid GF, de Olmos JS, Beltramino CA (1995) Amygdala and extended amygdala. In: The rat nervous system (Paxinos $G$, ed), pp 495-578. San Diego: Academic.

Amaral DG, Witter MP (1995) Hippocampal formation. In: The rat nervous system (Paxinos G, ed), pp 443-493. San Diego: Academic.

Arató M, Bánki C, Bissette G, Nemeroff CB (1989) Elevated CSF CRH in suicide victims. Biol Psychiatry 25:255-359.

Arnold FJL, Bueno MD, Shiers H, Hancock DC, Evan GI, Herbert J (1992) Expression of c-fos in regions of the basal limbic forebrain following intracerebroventricular corticotropin-releasing factor in unstressed or stressed male rats. Neuroscience 51:377-390.

Bánki CM, Karmacsi L, Bissette G, Nemeroff CB (1992a) Cerebrospinal fluid neuropeptides in mood disorder and dementia. J Affect Disord $25: 39-45$.

Bánki CM, Karmacsi L, Bissette G, Nemeroff CB (1992b) CSF corticotropin-releasing hormone and somatostatin in major depression: response to antidepressant treatment and relapse. Eur Neuropsychopharmacol 2:107-13.

Campeau S, Davis M (1995) Involvement of the central nucleus and basolateral complex of the amygdala in fear conditioning measured with fear-potentiated startle in rats trained concurrently with auditory and visual conditioned stimuli. J Neurosci 15:2301-2311.

Campeau S, Miserendino MJD, Davis M (1992) Intra-amygdala infusion of the N-methyl-D-aspartate receptors antagonists AP5 blocks acquisition but not expression of fear-potentiated startle to an auditory conditioned stimulus. Behav Neurosci 106:569-574.

Canteras N, Swanson L (1992) Projections of the ventral subiculum to the amygdala, septum, and hypothalamus: a PHAL anterograde tracttracing study in the rat. J Comp Neurol 324:180-194.

Chalmers D, Lovenberg TW, De Souza EB (1995) Localization of novel corticotropin-releasing factor receptor (CRF2) mRNA expression to specific subcortical nuclei in rat brain: comparison with CRF1 Receptor mRNA expression. J Neurosci 15:6340-6350.

Charney DS, Deutch AY, Krystal JH, Southwick SM, Davis M (1993) Psychobiology mechanisms of posttraumatic stress disorder. Arch Gen Psychiatry 50:295-305.

Cullinan WE, Herman JP, Watson SJ (1993) Ventral subicular interaction with the hypothalamic paraventricular nucleus: evidence for a relay in the bed nucleus of the stria terminalis. J Comp Neurol 332:1-20.

Cummings S, Elde R, Ells J, Lindall A (1983) Corticotropin-releasing factor immunoreactivity is widely distributed within the central nervous system of the rat: an immunohistochemical study. J Neurosci 3:1355-1368.

Darnell A, Bremer JD, Licino J, Krystal J, Nemeroff CB, Owens M, Erdos J, Charney DS (1994) CSF levels of corticotropin releasing factor I chronic post-traumatic stress disorder. Soc Neurosci Abstr 20:17.

Davis M, Astrachan DI (1978) Conditioned fear and startle magnitude: effects of different footshock or backshock intensities used in training. J Exp Psychol Anim Behav Process 495-103.

Davis M, Gendelman DS, Tischler MD, Gendelman PM (1982) A primary acoustic startle circuit: lesion and stimulation studies. J Neurosci 2:791-805.

Davis M, Gewirtz J, McNish K (1995) Effects of amygdala lesions vs lesions of the bed nucleus of the stria terminalis on explicit cue vs contextual fear conditioning. Soc Neurosci Abstr 21:1224.

de Olmos J, Alheid GF, Beltramino CA (1985) Amygdala. In: The rat nervous system, Vol 1, Forebrain and midbrain (Paxinos G, ed), pp 223-334. Orlando, FL: Academic.

De Souza EB, Perrin MH, Insel TR, Rivier JE, Vale WW, Kuhar MJ 
(1984) Corticotropin-releasing factor receptors in rat forebrain: autoradiographic identification. Science 224:1449-1451.

Dunn AJ, Berridge CW (1990) Physiological and behavioral responses to corticotropin-releasing factor administration: is CRF a mediator of anxiety or stress responses? Brain Res Rev 15:71-100.

Elkabir DR, Wyatt ME, Vellucci SV, Herbert J (1990) The effects of separate or combined infusions of corticotropin-releasing factor and vasopressin either intraventricularly or into the amygdala on aggressive and investigative behavior in the rat. Regul Pept 28:199-214.

France RD, Urban B, Krishnan KRR, Bissett G, Bánki CM, Nemeroff C, Speilman FJ (1988) Corticotropin-releasing factor-like immunoreactivity in chronic pain patients with and without major depression. Biol Psychiatry 23:86-88.

Gray TS (1990) The organization and possible function of amygdaloid corticotropin-releasing factor pathways. In: Corticotropin-releasing factor: Basic and clinical studies of a neuropeptide (De Souza EB, Nemeroff CB, eds), pp 53-68. Boca Raton, FL: CRC.

Gray TS (1993) Amygdaloid CRF pathways. Role in autonomic, neuroendocrine, and behavioral responses to stress. Ann NY Acad Sci 697:53-60.

Gray TS, Magnuson DJ (1987) Neuropeptide neuronal efferents from the bed nucleus of the stria terminalis and central amygdaloid nucleus to the dorsal vagal complex in the rat. J Comp Neurol 262:365-374.

Gray TS, Magnuson DJ (1992) Peptide immunoreactive neurons in the amygdala and the bed nucleus of the stria terminalis project to the midbrain central gray in the rat. Peptides 13:451-460.

Gray TS, Piechowski RA, Yracheta JM, Rittenhouse PA, Bethea CL, Van de Kar L (1993) Ibotenic acid lesions of the bed nucleus of the stria terminalis attenuate conditioned stress-induced increases in prolactin, ACTH and corticosterone. Neuroendocrinology 57:517-524.

Heinrichs SC, Pich EM, Miczek KA, Britton KT, Koob GF (1992) Corticotropin-releasing factor antagonist reduces emotionality in socially defeated rats via direct neurotropic action. Brain Res 581:190-197.

Helmstetter FJ, Bellgowan PS (1994) Effects of muscimol applied to the basolateral amygdala on acquisition and expression of contextual fear conditioning in rats. Behav Neurosci 108:1005-1009.

Hitchcock JM, Davis M (1986) Lesions of the amygdala, but not of the cerebellum or red nucleus, block conditioned fear as measured with the potentiated startle paradigm. Behav Neurosci 100:11-22.

Hitchcock JM, Davis M (1987) Fear-potentiated startle using an auditory conditioned stimulus: effect of lesions of the amygdala. Physiol Behav 39:403-408.

Hitchcock JM, Davis M (1991) Efferent pathway of the amygdala involved in conditioned far as measured with the fear-potentiated startle paradigm. Behav Neurosci 105:826-842.

Holstege G, Meiners L, Tan K (1985) Projections of the bed nucleus of the stria terminalis to the mesencephalon, pons, and medulla oblongata in the cat. Exp Brain Res 58:379-391.

Honkaniemi JT (1992) Colocalization of peptide- and tyrosine hydroxylase-like immunoreactivities with Fos-immunoreactive neurons in rat central amygdaloid nucleus after immobilization stress. Brain Res 598:107-113.

Honkaniemi JT, Kainu T, Ceccatelli S, Rechardt L, Hökfelt T, PeltoHuikko M (1992) Fos and jun in rat central amygdaloid nucleus and paraventricular nucleus after stress. NeuroReport 3:849-852.

Imaki T, Shibasaki T, Hotta M, Demura H (1993) Intracerebroventricular administration of corticotropin-releasing factor induces c-fos mRNA expression in brain regions related to stress responses: comparison with pattern of c-fos mRNA induction after stress. Brain Res 616:114-125.

Lee EH, Tsai MJ (1989) The hippocampus and amygdala mediate the locomotor stimulating effects of corticotropin-releasing factor in mice. Behav Neural Biol 51:412-423.

Lee Y, Davis M (1997) Role of the septum in the excitatory effect of corticotropin-releasing hormone on the acoustic startle reflex. J Neurosci 17:6424-6433.

Lee Y, López DE, Meloni EG, Davis M (1996) A primary acoustic startle pathway: obligatory role of cochlear root neuron and the nucleus reticularis pontis caudalis. J Neurosci 16:3775-3789.

Liang KC, Lee EH (1988) Intra-amygdala injections of corticotropinreleasing factor facilitate inhibitory avoidance learning and reduce exploratory behavior in rats. Psychopharmacology (Berl) 96:232-236.

Liang KC, Melia KR, Campeau S, Falls WA, Miserendino MJD, Davis M (1992) Lesions of the central nucleus of the amygdala, but not the paraventricular nucleus of the hypothalamus block the excitatory effects of corticotropin-releasing factor on the acoustic startle reflex. J Neurosci 12:2313-2320.

Lovenberg TW, Liaw CW, Grigoriadis DE, Clevenger W, Chalmer DT, De Souza EB, Oltersdorf T (1995) Cloning and characterization of a functionally distinct corticotropin-releasing factor receptor subtype from rat brain. Proc Natl Acad Sci USA 92:836-840.

Makino S, Gold PW, Schulkin J (1994a) Corticosterone effects on corticotropin-releasing hormone mRNA in the central nucleus of the amygdala and the parvocellular region of the paraventricular nucleus of the hypothalamus. Brain Res 640:105-112.

Makino S, Gold PW, Schulkin J (1994b) Effects of corticosterone on CRH mRNA and content in the bed nucleus of the stria terminalis: comparison with the effects in the central nucleus of the amygdala and the paraventricular nucleus of the hypothalamus. Brain Res 657:141-149.

Makino S, Schulkin J, Smith MA, Pacak K, Palkovits M, Gold PW (1995) Regulation of corticotropin-releasing hormone receptor messenger ribonucleic acid in the rat brain and pituitary by glucocorticoids and stress. Endocrinology 136:4517-4525.

Mamalaki E, Kvetnansky R, Brady LS, Gold PW (1992) Repeated immobilization stress alters tyrosine hydroxylase, corticotropin-releasing hormone and corticosteroid receptor messenger ribonucleic acid levels in rat brain. J Neuroendocrinol 4:689-699.

Menzaghi F, Rassnick S, Heinrichs S, Baldwin H, Pich EM, Weiss F, Koob GF (1994) The role of corticotropin-releasing factor in the anxiogenic effects of ethanol withdrawal. Ann NY Acad Sci 739:176-184.

Moga MM, Saper CB, Gray TS (1989) Bed nucleus of the stria terminalis: cytoarchitecture, immunohistochemistry, and projection to the parabrachial nucleus in the rat. J Comp Neurol 293:315-332.

Möller C, Bing O, Heilig M (1994) c-fos expression in the amygdala: in vivo antisense modulation and role in anxiety. Cell Mol Neurobiol $14: 415-423$

Nemeroff CB, Wiswelöv E, Bissette G, Walléus H, Karlsson I, Eklund K, Kilts CD, Loosen RT, Vale W (1984) Elevated concentration of CSF corticotropin-releasing factor-like immunoreactivity in depressed patients. Science 226:1342-1343.

Pich EM, Lorang M, Yeganeh M, Rodriguez de Fonseca F, Raber J, Koob GF, Weiss F (1995) Increase of extracellular corticotropinreleasing factor-like immunoreactivity levels in the amygdala of awake rats during restraint stress and ethanol withdrawal as measured by microdialysis. J Neurosci 15:5439-5447.

Post RM, Ballenger JC, Uhde TW, Putman Jr FW, Bunney WE (1981) Kindling and drug sensitization: implications for the progressive development of psychopathology and treatment with carbamazepine. In: The psychopharmacology of anticonvulsant (Sandler M, ed), pp 27-53. Oxford: Oxford UP.

Rassnick S, Heinrichs SC, Britton KT, Koob GF (1993) Microinjection of a corticotropin-releasing factor antagonist into the central nucleus of the amygdala reverses anxiogenic-like effects of ethanol withdrawal. Brain Res 605:25-32.

Sakanaka M, Shibasaki T, Lederis K (1986) Distribution and efferent projections of corticotropin-releasing factor-like immunoreactivity in the rat amygdaloid complex. Brain Res 382:213-238.

Sakanaka M, Shibasaki T, Lederis K (1987) Corticotropin-releasing factor-like immunoreactivity in the rat brain as revealed by a modified cobalt-glucose oxidase-diaminobenzidine method. J Comp Neurol 260:256-298.

Sananes CB, Davis M (1992) N-Methyl-D-aspartate lesions of the lateral and basolateral nuclei of the amygdala block fear-potentiated startle and shock sensitization of startle. Behav Neurosci 106:72-80.

Sawchenko PE, Swanson LW (1985) Localization, co-localization and plasticity of corticotropin-releasing factor immunoreactivity in rat brain. Fed Proc 44:221-227.

Schwaber J, Kapp BS, Higgins G (1980) The origin and extent of direct amygdala projections to the region of the dorsal motor nucleus of the vagus and the nucleus of the solitary tract. Neurosci Lett 20:15-20.

Sofroniew MW (1983) Direct reciprocal connections between the bed nucleus of the stria terminalis and dorsomedial medulla oblongata: evidence from immunohistochemical detection of tracer protein. J Comp Neurol 213:399-405.

Sun N, Roberts L, Cassell MD (1991) Rat central amygdaloid nucleus projections to the bed nucleus of the stria terminalis. Brain Res Bull 27:651-662.

Swanson LW, Simmons DM (1989) Differential steroid hormone and 
neural influences on peptide mRNA levels in CRH cells of the paraventricular nucleus: a hybridization histochemical study in the rat. J Comp Neurol 285:413-435.

Swanson LW, Mogenson GJ, Gerfen CR, Robinson P (1984) Evidence for a projection from the lateral preoptic area and substantia innominata to the "mesencephalic locomotor region" in the rat. Brain Res 295:161-178.

Swiergiel AH, Takahashi LK, Kalin NH (1993) Attenuation of stressinduced behavior by antagonism of corticotropin-releasing factor receptors in the central amygdala in the rat. Brain Res 623:229-234.

Takeuchi Y, McLean JH, Hopkins DA (1982) Reciprocal connections between the amygdala and parabrachial nuclei: ultrastructural demonstration by degeneration and axonal transport of horseradish peroxidase in the cat. Brain Res 239:583-588.

Takeuchi Y, Matsushima S, Matsushima R, Hopkins D (1983) Direct amygdaloid projections to the dorsal motor nucleus of the vagus nerve: a light and electron microscopic study in the rat. Brain Res 280:143-147.

Uryu K, Okumura T, Shibasaki T, Sakanaka M (1992) Fine structure and possible origins of nerve fibers with corticotropin-releasing factorlike immunoreactivity in the rat central amygdaloid nucleus. Brain Res 577:175-179.

Veening JG, Swanson LW, Sawchenko PE (1984) The organization of projections from the central nucleus of the amygdala to brainstem sites involved in central autonomic regulation: a combined retrograde transport-immunohistochemical study. Brain Res 303:337-357.

Walker DL, Davis M (1996) AMPA receptor blockade in the bed nucleus of the stria terminalis (BNST) but not the central nucleus of the amygdala (CeA) disrupts light-enhanced startle: a novel paradigm for the assessment of anxiety in rats. Soc Neurosci Abstr 22:1117.

Walker DL, Davis M (1997) Anxiogenic effects of high illumination levels assessed with the acoustic startle response. Biol Psychiatry, in press. 